\title{
EL MENDIGO, EL TRAVESTI, LA TELEVISIÓN. TEATRALIDAD URBANA Y ESPECTÁCULO EN LA POESÍA DE ENRIQUE LIHN ${ }^{1}$
}

\author{
Matías Ayala \\ Universidad de Talca \\ mayala@utalca.cl
}

RESUMEN / ABSTRACT

Este artículo presenta la teatralidad en la poesía de Enrique Lihn como forma de articular lo colectivo y lo político en el espacio urbano y el espectáculo mediático. Tres momentos se presentan. Primero, el mendigo como espectáculo urbano de la pobreza. Segundo, el travesti como sujeto en donde las miradas se cruzan. Por último, la figura de la televisión y la tortura como dobles opuestos de visibilidad e invisibilidad mediática e importancia política.

Palabras Clave: Lihn, poesía, teatralidad, política, ciudad, mendigo, travesti, tortura.

This article focuses on theatricality in Enrique Lihn's poetry as a way of articulating the collective, the urban, and the media spectacle in three moments of expression. Firstly, the beggar as urban spectacle of poverty. Secondly, the transvestite as a subject upon whom gazes intersect. Finally, the figures of television and torture as opposed in terms of media and political influence, visibility and invisibility.

KEY WORDS: Lihn, poetry, theatricality, politics, city, beggar, transvestite, torture.

1 Este artículo se enmarca dentro del proyecto de investigación Fondecyt Regular número 1110020, Conicyt, Chile. 
Se suele pensar la teatralidad en la poesía del chileno Enrique Lihn (19291988) como una extensión de su poesía lírica. Así, ella comenzaría en los monólogos dramáticos de La pieza oscura (1963), seguiría al mezclarse con la lírica (en La musiquilla de las pobres esferas de 1969, por ejemplo) y desembocaría en el personaje Pompier que creó Lihn (el cual encarnó en un escenario en 1977 y fue el protagonista de la novela El arte de la palabra). Casos en donde la lírica se funde con lo teatral se encuentran en toda su poesía, incluso en sus momentos más intelectuales y abstractos. Todo esto ya ha sido considerado por la crítica (Lastra 134, Ostria 53), sin embargo, hay una segunda instancia de la teatralidad en Lihn que no ha sido tan notada: la que se da en el espacio urbano y el espectáculo televisivo. Eso será el tema de estas páginas.

La poesía urbana de Enrique Lihn de los años 70 y 80 se suele interpretar a partir del viaje (A partir de Manhattan de 1979, Pena de extrañamiento de 1986) y la crónica (El paseo Ahumada de 1983, La aparición de la virgen de 1987); al menos esa es la división que hace Carmen Foxley en su libro sobre Lihn y que repiten, por ejemplo, G. Favi, O. Galindo y A. Valdés. Yo quisiera leer estos libros no desde ese patrón temático (el viaje, la ciudad) sino desde la teatralidad como forma de articular el sujeto y su entorno en la mirada y los cuerpos, el espacio y las relaciones sociales. La poesía de Lihn presenta el espacio urbano como un escenario en donde los sujetos devienen personajes que se ofrecen a la mirada pública. Si bien C. Travis en Resisting Alienation (213-215) propone leer El paseo Ahumada y La aparición de la virgen también a partir de la teatralidad, su clave de lectura sigue la interpretación que R. Cánovas hace del paródico personaje Pompier. R. Cánovas, sin complicarse, interpreta a Pompier como la inversión carnavalesca que M. Bajtin notó en la obra de F. Rabelais con la máscara y el juego del carnaval como elementos principales (40). Esta lectura creo que no solo limita la complejidad y la potencia política de la obra de Lihn sino que además no se ajusta a su obra ya que la figura del cuerpo abierto, fértil y superabundante -fundamental para Rabelais y Bajtin- no se aplica a Lihn, así como tampoco lo hace en la celebración gozosa de la cultura popular. Por otra parte, Luis Correa-Díaz leyó una cierta teatralidad en El paseo Ahumada (135-145) pero la propuso como una proyección del sujeto poético - es decir, la recondujo a la lírica-, lo que él llama el "ventriloquismo" en donde persiste un sujeto detrás de la máscara exhibida. Aquí, en cambio, se lee la teatralidad de la poesía de Enrique Lihn no como una extensión subjetiva sino como figuración de lo colectivo en el espacio urbano, intensidad de las miradas sociales que exhiben, 
cruzan y desencuentran. La teatralidad es el espectáculo social y político del espacio urbano y el televisivo.

W. Egginton en How the World Became a Stage propone entender la teatralidad no solo como una cierta performance pública o emocionalidad y autoconciencia del actor, sino como un medio de interacción cuyas convenciones estructuran y nos revelan nuestro sentido del espacio o espacialidad (3). Egginton nota cómo la distancia física del escenario construye un espacio muy particular con sus propias reglas. El espectador, entonces, acepta la ficcionalidad de la narrativa teatral a pesar de que distingue al actor del personaje, es decir, a pesar de nunca olvidar que tiene al frente una ficción. Esta aceptación de la ficción (emoción) a pesar de reconocer su artificio (distanciamiento) es una clave en la poética lihneana. Samuel Weber lo propone de manera más compleja al sugerir que la indeterminación es la figura central de la teatralidad, ya que es "lugar de disimulo y engaño, de auto-disimulo y auto-engaño" (8). No solo el espectador acepta la ficción y artificio, sino que también confunde apariencia y realidad hasta ser incapaz de dilucidar qué elemento pertenece a qué orden. Esta indeterminación entre lo imaginario y lo real no solo se aplica al teatro sino que se puede traspasar a la literatura, de hecho, será un argumento que Lihn esgrimirá como forma de separar su labor literaria del realismo, y de ligarla, al mismo tiempo, a la política. Así propuso en 1984: "Quise hacerle un lugar en la imaginación o, más bien, tocar el punto en que lo imaginario y lo real se confunden al punto tal que ya no pueden descomponerse sin perder, por separado, todas sus propiedades" (Entrevistas 180).

En la poesía de Lihn el espacio público de la ciudad -veredas, calles, bulevares, estaciones de metro- toman el lugar de escenarios en donde personajes se exhiben a la mirada colectiva del público. Más que la calle como el lugar de encuentro o el cruce de las miradas -como sostiene al famoso soneto de Charles Baudelaire $\grave{A}$ une passante en el que Walter Benjamin se basó para escribir "París, capital del siglo XIX"-algunos se muestran y otros miran. Los que se muestran, por una parte, se desdoblan en personajes cuyos cuerpos y vestimentas, sus gestos y subjetividades son excepcionales, es decir, su sola presencia deviene un espectáculo a la mirada ajena ya sea por atractivo o repulsivo. Ellos ostentan un exceso visual que elude la normalidad y normatividad y así encarnan -como símbolos más o menos directos o alegorías encriptadas- una cierta interpretación de lo colectivo.

Frente a ellos se encuentra el sujeto lírico que articula e interpreta la relación entre su propia mirada y corporalidad del otro. Este desencuentro 
de las miradas es asegurado si el sujeto está escondido en la muchedumbre, por esto, para Lihn, la mirada urbana se encarna en la figura del voyeur: el que mira sin ser visto. La mirada es voyerista para Lihn porque en ella el sujeto está protegido de la mirada, el cuerpo y el deseo del otro. Protegido en un narcisismo, nunca aspira a reconocer al otro, tampoco a la mirada de la ley, preso de su propia imagen especular.

En esta poesía en cambio, la calle es un espacio discontinuo y de encuentro con estos personajes que hacen un espectáculo de sí mismos. Para el sujeto, en términos de deseo, ellos pueden ser toda una gama de seductores, posados, simulados, grotescos hasta abyectos. Predicadores, músicos, ciegos, desempleados, jubilados, mendigos, prostitutas/os, travestis, drogadictos, son principalmente la galería de personajes con que se encuentran los que hacen del espacio público su lugar de trabajo y de vida. A veces también hay viajeros del metro, espectadores del teatro, cine o televisión. La descripción de estos cuerpos no se basa en el realismo de la crónica-como han observado erradamente algunos críticos-sino en un abanico que despliega la teatralidad.

En los libros de poesía de los años 60 de Enrique Lihn, la política suele tomar forma a través de la teatralidad. En dos poemas sobre el imperialismo norteamericano, el cuerpo se encuentra suplementado teatralmente. En "La invasión" de La pieza oscura (1963) en una sala de consejo militar aparece "una cabeza emplumada" como símbolo de la violencia (53-54) y en el largo y ensayístico "La derrota" de Poesía de paso (1966) los agentes encubiertos de la CIA aparecen en medio de un carnaval de carros alegóricos (100-1). Se podría decir, entonces, que la tendencia hacia la exhibición corporal como un registro político continúa cuando se concibe la teatralidad como evento público.

En las siguientes páginas se leerán tres momentos de la teatralidad urbana y el espectáculo. Primero, la figura del sujeto popular en El paseo Ahumada, que debe hacer de la mendicidad un espectáculo grotesco. Estos cuerpos son símbolos de la crisis del capitalismo en el represivo sistema político de la dictadura chilena. En la segunda parte, la figura del travesti se desdobla-para la mirada masculina- en atracción y repulsión. El travesti, si bien representa un personaje marginalizado socialmente, sobrepone a la mirada ajena su propia mirada como manera de resistencia. Finalmente, se leerá la figura de la tortura y la televisión como dobles opuestos de visibilidad e invisibilidad política. En estas tres figuras de la poesía de Lihn los cuerpos se presentan teatralmente y el texto hace una reflexión sobre la política y lo colectivo. 


\section{LOS MENDIGOS GROTESCOS DE EL PASEO AHUMADA}

El paseo Ahumada (1983), homónimo de la principal calle céntrica de Santiago de Chile convertida en paseo peatonal en 1978, resalta por su capacidad referencial. Su tema es el comercio ambulante y otra formas de trabajo "informales" que aumentan con la crisis económica de Chile de 1982 (la que se debió a las reformas liberales que implantó la dictadura militar). El paseo Ahumada deviene así el escenario de la mendicidad, en donde los trabajadores deben competir por la limosna al exhibir su cuerpo con patetismo. El dramatismo de la situación (pobreza, represión policial) es presentado con distancia cómica al ser concebido teatralmente. El mismo Lihn lo puso en su epílogo a este volumen:

Son razones de economía las que han convertido el Paseo, construido con objetivos menos interesantes, en el Gran Teatro de la crueldad nacional y popular, donde se practican todos los oficios de la supervivencia, desde los más espectaculares hasta los más secretos, sin que ninguno de ellos escape a la publicidad. El trabajo se ha convertido en un arte en el Paseo Ahumada y la mendicidad, en un trabajo altamente competitivo. El Show empieza cuando usted llega y no termina cuando usted se va. Y todos somos sus coautores, sus actores y sus espectadores. (El paseo Ahumada $\mathrm{s} / \mathrm{n}$ )

La exhibición del patetismo de la pobreza se compensa, ya que la "libre competencia" de la mendicidad debe ejercerse teatralmente. La ironía de El paseo Ahumada es que la crisis económica del 1982 partió como crisis bancaria -la crisis más abstracta del capitalismo-y ella desencadena la "libre competencia" de la mendicidad callejera. El capitalismo se ordena a partir y en la desigualdad ("los recursos son limitados y las necesidad infinitas" reza uno de sus lemas angulares). Que esto se dé en un contexto represivo -la policía dispuesta a reprimir cualquier manifestación- muestra la otra paradoja de la que Chile ha sido ejemplo característico: la implantación del capitalismo no necesita de la libertad política.

En "Su limosna es mi sueldo Dios se lo pague", el primer poema del libro, se introduce el que será el personaje principal del volumen y que aparece en la tapa del libro, el Pingüino: una suerte de discapacitado mental sin talento musical que toca una batería hecha de cajas de cartón con una pandereta encima. A él se dirigen varios poemas y así se invierte irónicamente la función del apóstrofe lírico: en vez de elevar el discurso, lo degrada. El Pingüino, 
además, es símbolo del desempleo y la pobreza que como último recurso debe recurrir a la teatralidad.

Su limosna es mi sueldo

Dios se lo pague

Un millón y medio de subempleados mendigos suscribirían el lema si los dejaran chillar como a éste y a otros tantos pocos en el Paseo Ahumada Se autoapoda El Pingüino y toca un tambor de cualquier cosa con su pezuña de palmípedo

Qué dislocado sentido del humor

Toca que toca sin son ni ton zapateo

de un epiléptico en tren de espectacularse

el graznido de un palo

Privilegiados son él y otros mendigos de verdad a quienes les está permitido ir derecho al grano de limosna

como en su caso, a veces, sin ningún mérito artístico

Privilegiado el ciego que toca su flauta dulce a la vaciada luz de esta luna

Privilegiado el sordo del acordeón, artista exclusivo de la Radio-Noche y el mudo que lisa y llanamente canta

-el que quiere celeste que le cueste-

En Huérfanos entre Ahumada y Estado las papas de la mendicidad se están quemando dulcemente

Privilegiada la Volada, que estropajosa de niños forma con ellos un túmulo prefunerario, porque de ella es el reino de la Mendicidad

Privilegiados todo ellos porque de estos corderos está hecho el rebaño de los casos omisos

¿eh, Pingüino? A ti nadie te toca un pelo

Caso omiso hacen de todos ustedes esos robots que se mueven armados hasta los dientes

con sus lobos de mano y sus metralletas eléctricas.

(El paseo Ahumada s/n)

El Pingüino se presenta aquí como privilegiado de poder "trabajar" en el céntrico paseo Ahumada debido a su escaso talento musical. Por esto el lema "Su limosna es mi sueldo" -patético agradecimiento de la mendicidad- es anhelado por los demás ciudadanos que se encuentran aún en peor situación social y laboral. El poema presenta su cuerpo como si fuera un pingüino -toma su apodo animal y lo extiende a su apariencia física-, lo animaliza y lo describe 
de forma grotesca y monstruosa: "y toca un tambor de cualquier cosa con su pezuña de palmípedo". La descripción del Pingüino es dramática y ridícula al mismo tiempo, hecha en un lenguaje coloquial y con un cómico neologismo: "zapateo / de un epiléptico en tren de espectacularse". La arenga del resto del poema se dirige a los necesitados y parodia el pasaje bíblico conocido como "El sermón de la montaña" (Mateo 5:1-11, Lucas 7:17-49) que se estructura sintácticamente con la repetición de "Bienaventurados..." al inicio de las frases. En ese sermón, Jesucristo les promete felicidad futura a los que sufren en este mundo y a los que acepten los valores espirituales que propugna. Lihn, reconduce el "bienaventurados" de ascendencia religiosa y psicológica en "privilegiados" de ascendencia económica y social. Finalmente, el poema propone que el Pingüino, los mendigos, el ciego, el sordo, el drogadicto (la Volada) son privilegiados porque son "casos omisos" de las fuerzas del orden, las que se preocupan de reprimir, en cambio, las manifestaciones políticas y no el exceso teatral de la mendicidad urbana.

Los mendigos crecen con el capitalismo en crisis: son sucios, no trabajan, no tienen ni el decoro burgués ni los valores del éxito. Su retrato es grotesco. Se suele describir lo grotesco como poseedor de elementos incongruentes que entran en conflicto: lo cómico y lo horroroso, lo maravilloso y lo siniestro, la empatía y la repulsión (Thomson 20). Durante el romanticismo, devino lo extraño y absurdo, distorsionado o fantástico. W. Kayser -el que el mismo Lihn cita a raíz de Rodrigo Lira (El circo en llamas 314)- propone que lo grotesco produce un distanciamiento en el lector (224), lo que aquí puede entenderse como el extrañamiento de lo teatral en el espectador. Los personajes de El paseo Ahumada poseen esta cualidad conflictiva que les da la exagerada teatralidad: son patéticos y risibles a la vez. Estos mendigos/ músicos son la única figuración de la masa proletaria, del sujeto popular bajo constreñimiento social y político en la poesía de Lihn.

Estos personajes marginales urbanos se encuentra no lejanos al retrato de drogadictos en Nueva York ${ }^{2}$ o de borrachos en San Francisco ${ }^{3}$. En todos ellos la marginalidad urbana no estetiza su apariencia ni es idealizada en su capital político sino que ella toma cuerpo teatralmente en el espacio urbano. Es decir, ellos devienen personajes visibles de la ciudad como escenario de la política.

2 "La caricatura" y "La risa abunda en la boca de los jóvenes" de Pena de extrañamiento.

3 "Homenaje a Carol Doda, el sueño de David" y "El estilo es el vómito" de A partir de Manhattan. 
Como propuso J. Rancière la política se entiende aquí como emparentada con la estética, ya que es una "distribución de lo sensible": lo determina lo visible y lo invisible, los que cuentan y no cuentan en el discurso público, los que tienen derecho a hablar y los que no lo tienen (13-14). La literatura entonces puede definir modelos de visibilidad, de relaciones entre lo visible y decible, de relaciones entre modelos de ser, hacer y decir (62). Estos sujetos urbanos de la poesía de Lihn toman cuerpo y así devienen sujetos políticos.

\section{EL TRAVESTI BAJO LAS MIRADAS MASCULINAS}

En la otra vereda en la poesía de Lihn, los que hacen un espectáculo de su cuerpo a la mirada urbana son la prostituta y el travesti. Como los mendigos y los músicos callejeros, utilizan la calle como escenario y lugar de trabajo. Además, exhiben su propio cuerpo como mercancía ya que venden su sexualidad. "El vaciadero", poema que abre A partir de Manhattan, es la descripción de una calle dedicada a la prostitución en donde la degradación corporal se identifica con la degradación urbana y la pobreza económica:

No se renueva el personal de esta calle:

el elenco de la prostitución gasta su último centavo en maquillaje

bajo una luz polvorienta que se le pega a la cara.

Una doble hilera de caries, dentadura de casas desmoronadas

es la escenografía de esta Danza Macabra

trivial bailongo sabatino en la pústula de la ciudad.

Es una cara conocida llena de costurones con lívidas cicatrices bajo unos centavos de polvo, y que emerge de todas las grietas

de la ciudad, en este barrio más antiguo que el Barrio de los Alquimistas como la cara sin cuerpo del caracol ofreciéndose en los dos sexos de su cuello andrógino

blandamente fálico y untado de baba vaginal

el busto de un boxeador que muestra las tetas en el marco de un socavón.

No avanza ni retrocede el río en este tramo descolorido y bullente alrededor de la compuerta

El mecanismo de un reloj descompuesto cuelga como la tripa de un pescado de la mesita de noche

entre los rizos de una peluca rosada

La fermentación de las aguas del tiempo que se enroscan alrededor del 
detritus como el caracol en su concha el éxtasis de lo que por fin se pudre para siempre.

(A partir de Manhattan 11-12)

Las prostitutas y los cuerpos de este poema no se encuentran individualizados. Es más, su degradación, al mismo tiempo vital y social -envejecimiento y pobreza- hace que estos personajes se identifiquen con el escenario: una calle que se retrata a la vez teatralmente sórdida, biológicamente enferma y visualmente confusa: "Una doble hilera de caries, dentadura de casas desmoronadas / es la escenografía de esta Danza Macabra”. En la segunda estrofa el cuerpo del travesti es descrito no como un cambio en la vestimenta o maquillaje que confunde los roles tradicionales de género sino como un mítico cuerpo andrógino, es decir, con aparatos sexuales masculinos y femeninos en distintos estados de desarrollo. La precisión con que nombra los órganos sexuales asociados al cuerpo informe de un caracol vuelve a este poema perturbador y repulsivo. Al detenerse en el cuerpo indeterminado del molusco -el que sí puede ser hermafrodita- el poema logra este efecto desagradable.

Los efectos de asco no solo se logran a través del cuerpo del travesti animalizado y vuelto hermafrodita como el caracol, sino que además mediante los cuerpos abiertos ("dentadura de casas desmoronadas", "pústula de la ciudad", "tripa de un pescado") y efectos de sensaciones táctiles y olfativas (caracol baboso, aguas con detritus). La última estrofa cumple esta función de producir asco a través de una yuxtaposición de interiores de animales con interiores urbanos (no lejano del Neruda de Residencia en la tierra, curiosamente). Si bien el asco es una sensación física y estética no es meramente individual, pues implica fuertes valoraciones culturales. En el asco funciona una frontera moral y social que mantiene la distancia con una alteridad y heterogeneidad sexual, animal y corporal. Frente a los patrones de belleza clásica idealizada que producen placer y fomentan el deseo, la cercanía física y la fantasía de la unión, como observó Menninghaus, el asco es su doble opuesto, es ante lo que hay que apartarse y desarrollar un mecanismo de defensa (1-2).

Por otra parte, el poema "La Efímera Vulgata" de Pena de extrañamiento (35-41) -basado en fotografías de travestis de Luis Poirot, Barry Kay y posiblemente Paz Errázuriz- elabora largamente su exhibición en la calle ${ }^{4}$.

$4 \quad$ El poema fue publicado por primera vez con el título "As a woman" en la revista Hora de poesía 16-17 (1982) con una nota introductoria del mismo Lihn. Así comienza el texto de Lihn: "As a woman es el titulo de la recopilación de fotografías reunidas en libro 
El poema se desencadena a partir de la mirada de las fotografías, aunque se puede conjeturar que también a partir de la vista directa de ellos en Nueva York y Barcelona ${ }^{5}$ En "La Efímera Vulgata", en una primera impresión, en el poema no aparece articulada esta mediación fotográfica directamente. Tan solo se deduce de la multiplicidad de lugares geográficos que aparecen nombrados. Frente a estas distintas ciudades, la figura de La Efímera Vulgata es símbolo que condensa una variedad de travestis. Comienza el poema:

En un barrio de Sydney en la Rambla de Sitges

(cuando los padres han recogido a sus niños)

A medianoche cuando la Cenicienta pierde, alocada y astuta

uno de sus zapatitos en manos de las doce campanadas

en el Café de la Opera, en la casa de la Carlina

en Christopher Street

se despierta la efímera Vulgata para su vuelo nupcial

Despliega, como en las viejas tarjetas postales, sus alas de seda pintadas de lentejuelas

Los ojos son ocelos que relumbran al contacto de la luz y brillan con languidez.

(Pena de extrañamiento 35)

Sidney, Sitges, Christopher Street (calle del West Village, Nueva York que en los años 70 devino ícono de la cultura gay), Café de la Opera (tradicional local de Barcelona) son distintos lugares en donde emerge este símbolo del travesti: La Efímera Vulgata. El nombre del poema, elegido por el fotógrafo, quiere ser una figura de lo fugaz, nombre científico de una mariposa de corta vida $^{6}$. Así el poema expande la metáfora del travesti como mariposa: el

obra de Barry Kay, sobre el travestismo de una comunidad transexual establecida en la zona cosmopolita, turística de Sydney, Australia. El libro, formado por retratos individuales o de grupo, fue publicado en Londres y Nueva York en el año 1976. [...] Pero, el primer motor del siguiente texto es otro libro de imágenes, desafortunadamente inédito, trabajo de Lucho Poirot, fotógrafo chileno radicado en Barcelona. Poirot ha reunido, bajo el titulo exacto de Efimera Vulgata, una variedad de los insectos lepidópteros, que nacen y mueren como mariposas en la noche de su vuelo nupcial" (113).

El poema "Apología y condenación de las ramblas" de A partir de Manhattan, de hecho, consiste en la mirada de travestis en la Rambla de Barcelona.

$6 \quad$ El fotógrafo Poirot publicó en su blog el sábado 11 de agosto del 2007: "En Sitges, pequeño pueblo cerca de Barcelona, revivió el carnaval, fiesta pagana por excelencia, celebrada 
vestido son sus alas; sus ocelos, ojos; su vuelo, el desfile por las calles, etc. Asimismo, con esto Lihn utiliza un lenguaje delicado e infantilizado, como su comparación con la historia de la Cenicienta que se disfraza una noche, pierde un zapato y espera al príncipe ideal. La visión de ellos no enfatiza su identificación con el contexto degradado con efectos repulsivos-como en "El vaciadero"- sino que se detiene in extenso en la representación de su cuerpo:

Ante el espejo abominable

cópula que multiplica el número de lo mismo

alza el busto - ese simulacro-y miente la voluptuosidad con que acaricia senos que -si no tiene- existen por el milagro doloroso de la silicona

Despereza con las manos, a veces velludas

empinándose, el cuerpo desesperadamente sin nalgas

El reloj -todavía masculino- marca la hora

en que esta cenicienta debe atrapar a su príncipe

-aparición invertida que lo haga caer, como en una trampa, en lo que no eslos pies grandes en los zapatos estrechos (35)

Esta descripción corporal es una de las más exhaustivas que es posible encontrar en toda la poesía de Enrique Lihn. Es sintomático, no obstante, que ella sea la descripción de un sujeto que muestra la disyunción entre su cuerpo y la ropa, el género y el sexo. En esta estrofa el sujeto representado mira en el espejo su propia imagen, pero sobre todo, el sujeto de enunciación del poema mira el cuerpo del travesti y lo interpreta para los lectores. Las dos miradas que se cruzan en este espejo conforman dos cuerpos divergentes: el cuerpo que ve el propio travesti y el que el poema presenta. La famosa frase que desencadena la narrativa del cuento de Jorge Luis Borges "Tlön, Uqbar, Orbis Tertius", "los espejos y la cópula son abominables, porque multiplican el número de los hombres" (431), se reescribe para observar esta divergencia. El poema, en este fragmento, identifica con detalle las partes del cuerpo masculino que

cuarenta días antes de semana santa. Una vez caída la noche y terminado el previsible paso de inofensivos disfraces familiares, comenzaban a revolotear en las sombras de la calle las figuras de travestis no profesionales o necesariamente homosexuales. Durante un año entero prepararon sus trajes y maquillajes para en sólo una noche de deslumbramiento vivir quizás qué escondido sueño. Vagaban de bar en bar en la llamada "calle del pecado", dejando a su paso admiración o rechazo, nunca indiferencia. Durante tres años volví a Sitges atraído por estas mariposas de efímero vuelo nocturno". $<$ http://uispoirot.blogspot.com/2007/08/efmeravulgata.html $>$. Consultado el 15 de diciembre de 2011. 
revelan que no son femeninas y que muestran abiertamente el engaño (las fases entre guiones cumplen esa función redundantemente). Sin embargo, esto no se lleva a cabo como una denuncia, sino que hay un cierto placer irónico en la descripción, por ejemplo, "en el cuerpo desesperadamente sin nalgas", tan dramático como ridículo a la vez.

Judith Butler ha argumentado convincentemente cómo el travesti desarma las categorías de género, ya que no tiene una identidad sustancial, sino que se define por su persistente y continua performance. El género es, para Butler, una práctica eminentemente performativa, es decir, una práctica teatral: la repetición de una imitación certificada culturalmente. El travesti lleva esta idea al extremo y así muestra cómo el género y el sexo son construcciones sociales (137). Ese desajuste de las categorías de géneros se resalta en el poema con el cuerpo grotesco que el travesti ve en el espejo y que sale a exhibir a la calle con orgullo: "En los precitados rincones del mundo la rara flor se extiende centelleando / no por los prados de su imaginación sino por cafeterías y discotecas" (35-36). Este cuerpo que el travesti ve en el espejo no es el mismo que el hablante muestra. Esta separación es posible explicarla a partir de Jacques Lacan en su texto "El estadio del espejo como formador de función del yo...". Lacan propone que ego toma lugar cuando el infante aprehende la imagen de su cuerpo en una superficie reflectante como un espejo (100). El "sujeto" se identifica con esa imagen exterior y así puede articular su fragmentario cuerpo (que no controla ni conoce) como unitario. A este proceso Lacan lo llama un "desconocimiento" (méconnaissance) ya que el sujeto se identifica con algo que no es: una imagen invertida e idealizada de sí mismo, ya que está completa, organizada. Este proceso necesita ser triangulado por la mirada de los padres que confirma esta imagen como suya y que le dicen, por ejemplo, "ése eres tú".

Lihn, siguiendo a Lacan propone entonces que la imagen femenina que el travesti ve en el espejo no es la "real" sino que una imagen idealizada del sujeto: ficción de una mujer, fantasía como la Cenicienta, fantasma que está entremedio de lo real y lo irreal. "Phantasme" es, de hecho, la palabra francesa para "fantasía". Esta imagen ideal es un engaño con que el sujeto (de)forma su propia identidad. En el texto de Lihn sobre la fotografía de Paz Errázuriz se lee: "La imagen -imago o fantasma- que proyecta la Evelyn según el orden de su deseo no es la misma que percibe el espectador. Esta inadecuación, este desfase parecen constituir la fatalidad del travestido" (Textos sobre arte 361). Será la fatalidad del travesti, pero también es la fascinación de Lihn al constatar esa duplicidad entre estas dos imágenes, la 
del actor (masculino) y la del personaje (femenino). Por esto, el travesti sale a la calle para exhibirse como en un espectáculo, ya que la mirada ajena le debe certificar su identidad femenina.

Su propia imagen condensa en un solo personaje reconocidamente grotesca

a los otros dos polos: unión -en la contrariedad- de los contrarios mutuo desasosiego

Son los ojos de un hombre viejo

los que se clavan en el reflejo de sí mismos, sobre la máscara

de la prima donna... (39)

Este fragmento muestra cómo el cuerpo del travestis encarna estas dos miradas, la imagen idealizada y narcisista del travesti y la del otro (sujeto de enunciación, espectador, el lector masculino) las que jamás se juntan. Este desencuentro es insalvable y una síntesis de ella solo es posible de forma fantástica o paródica:

Quizá un cuarto sexo -ente numinoso- caiga atraído esa noche: un rayo sobre la rambla y se cumpla el milagro de la transfiguración de Cenicienta en el azul del príncipe que acaricia con ansiedad el zapatito de las doce (38)

En el resto de "La Efímera Vulgata" se ofrecen otras posiciones en torno al cuerpo y la imagen, la ley y el deseo. Primeramente, se da cabida a la mirada misma del travesti sobre su propio cuerpo y cómo ella solo ve el personaje que encarna (imagen ideal, la mujer, lo femenino). Se encuentra también el deseo del travesti mismo que anhela su príncipe azul. Además, están las distintas posiciones del deseo en los espectadores masculinos. Por ejemplo, hay los espectadores que han deseado ser mujer y por eso se reprimen a través de la repulsión: "Los que alguna vez se han soñado mujer (y su nombre es legión) / abominan del ejército de las locas" (36). Se encuentran también los que han deseado los travestis inconscientemente (como el paciente del "caso Schreber" sobre el cual Freud escribió) y se proyectan en ellos: "Los soñadores cuyos sueños en la hora de la consulta / no parecen, por su vulgaridad, llamar la atención del analista / se despiertan feminizados de la noche a la mañana como el doctor Schreber..." (36-37). Y, además, están los espectadores, como el hablante del poema, que tienen una posición intermedia, la combina repulsión y fascinación con el espectáculo de la disyunción entre 
sexo y género, imagen ideal e imagen real: "Nosotros ocupamos ese no lugar / tránsfugas del analista, satélites del doctor Schreber / los incompetentes voyeurs para los cuales / la perversión no es más que una ensoñación / o una pesadilla" (39-40).

El poema finaliza con una escena de la violencia en donde se revela la verdadera identidad del sujeto:

Unos segundos después de las doce campanadas

la Loca se precipita escaleras abajo

[...]

Las miradas del soplón, del voyeur y del príncipe desazulado se deslíen en el maquillaje -máscara que el flash derritey brota la identidad de esa calavera viviente (40).

La caída física del travesti que deshace su imagen ideal (el personaje) ya que la identificación del sujeto (actor) con la imagen de sí mismo debe llevarse a cabo bajo la mirada ajena (los padres, la ley, el otro). En el caso de "La Efímera Vulgata”, el travesti no logra sustentar su fantasía femenina en el texto. Por una parte, la imagen ideal siempre amenaza con fragmentar al cuerpo. Por otra, la mirada masculina del sujeto textual que restablece la verdad y reconoce engaño (quizá, en este poema, como esa forma reprimir el propio deseo). A pesar de este final en masculino, "La Efímera Vulgata" se ofrecen muchas más posiciones en torno al cuerpo y la imagen, la ley y el deseo. Primeramente, hay la mirada misma del travesti sobre su propio cuerpo y cómo ella solo ve al personaje que encarna (imagen ideal, la mujer, lo femenino). Frente a ella se mencionan las posiciones de mirada masculinas. Algunas de ellas admiran el individualismo del travesti, que es capaz de oponer su propia mirada a la mirada ajena, otras lo rechazan como narcisos incapaces de tomar en cuenta la mirada ajena.

\section{EL CUERPO SUFRIENTE Y LA TELEVISIÓN}

La última sección de este artículo corresponde al espectáculo. Hay en el espectáculo, sin embargo, un desplazamiento respecto a la teatralidad. Primero, que la presencia del cuerpo que se entrega a la mirada colectiva está ausente y mediado por una tecnología. El espectáculo se encuentra mediado por la televisión o el cine, y su materialidad es la proyección visual que se entrega en 
la pantalla. Segundo, la configuración del espacio no supone una continuidad corporal y perceptiva entre el espectador y el actor sino que los separa una discontinuidad: actor y espectador ahora se "encuentran" en la pantalla. El rasgo que persiste en la teatralidad y el espectáculo es la exhibición del cuerpo a la mirada colectiva. Este cuerpo, al estar descontextualizado y reducido a una imagen en una pantalla, permite, además, la proyección personal y literaria de deseos e identificaciones sobre él, ya que la "descorporalización" del sujeto visto no presenta una amenaza posible al sujeto (Mulvey 367-9). Lo que se revisará serán dos representaciones de cuerpos sufrientes, como espectáculo con distintos grados de visibilidad.

El opúsculo La aparición de la virgen (1987) nació de unas supuestas manifestaciones divinas que sucedieron en el cerro Membrillar de Peñablanca (Villa Alemana) en Chile en junio de 1983 y que duraron hasta 1988. Miguel Ángel Poblete, abandonado por su madre, creció en un hogar de menores. Dedicado a la vida marginal, subió al cerro a aspirar neoprén junto a un par de amigos y se les habría aparecido la virgen. Fue tanto el revuelo mediático y entre la población que acudieron miles a verlo. Reconocido como un joven histriónico, Miguel Ángel solía entrar en súbitos trances, hablar en lenguas desconocidas, transmitir mensajes de la virgen y profecías frente a las cámaras que multiplicaban su imagen. Como ese mismo año comenzaron en Chile una serie de protestas en contra de la dictadura -y la recesión se había hecho patente un año antes- distintos aparatos del Estado ayudaron a fomentar el impacto social de esta "aparición". De esta forma, muchos pensaron que la gran repercusión mediática de este evento se debió a una maniobra distractora del gobierno.

Aquí se reproduce completo el primer poema (sin título) de La aparición de la virgen, el que trenza represión política y espectáculo visual.

La realidad es el único libro que nos hace sufrir

La realidad es la única película que nos quita el sueño

Las apariciones de la Virgen serán irreales no así la aparición de los agentes de la realidad

Ellos son los únicos autores terribles Ellos son los únicos sádicos cineastas

La película con muchos años de rollo que hacen en sus recintos secretos Esa sí que desvela a sus actores

A las víctimas de la falange

A las víctimas de la bolsa de agua

A los intérpretes involuntarios de El interrogatorio a una madre 
Mil veces preferible quemarse los ojos para ver a la Virgen

Que estar en el elenco de los que filman con sangre

Sin una gota de luz

Dios me libre de ser escrito con sangre por uno de esos autores no identificados

Que filman y escriben en vivo y en directo

En sus cárceles secretas

Son esos los que no me dejan dormir tranquilo

(La aparición de la virgen 2)

Este poema afirma que la tortura es la única "realidad" frente a la aparición de la virgen. Tortura y aparición "divina" se oponen no solo como realidad y ficción, verdad y mentira, sino que además tienen una relación inversa de visibilidad e invisibilidad pública. La tortura, que se llevó a cabo a escondidas, fue una política de Estado sistemática durante la dictadura de Pinochet; en cambio, la aparición de la virgen es un espectáculo televisivo y popular señalado como excepcional y que cuenta una profusa cantidad de imágenes, tiempo y transmisión. Así, la luz marca una diferencia de visibilidad en el poema: entre "quemarse los ojos para ver a la Virgen" y "los que filman con sangre / Sin una gota de luz". Paradójicamente, este poema invierte aquello, ya que la forma de representar la tortura es a través de la filmación forzosa de una película, quizá un snuff film (la que también se lleva a cabo sin publicidad). La manera de figurar la tortura es a través del espectáculo, ya que así se logra un común denominador con el show televisivo. Los torturados toman el lugar de los actores, el tipo de tortura, el nombre de la película, solo que en la tortura real, a pesar de la irreal, los actores no se podrán separar de sus personajes, éste es el elemento siniestro del poema: como si el sueño -o más bien la pesadilla- se volviera realidad. Así, frente a la indistinción fantástica entre realidad y ficción, se suma la del actor y el personaje. Esta inestabilidad también se encuentra en el sujeto de enunciación del poema. Primero, se enuncia en primera persona plural: "nos hace sufrir", después los torturados están en tercera persona "las víctima de la bolsa de agua" y finalmente deja la posibilidad de la primera singular "los que no me dejan dormir tranquilo".

La escenificación de la tortura en este poema, si bien estetiza la violencia, la da una forma imaginaria. A esto se refería Lihn con llegar "a la verdad por lo imaginario" (Entrevistas 76). En otras palabras, si bien Lihn distingue la literatura de la realidad, es a través de la literatura misma que podemos 
llegar a comprender la realidad, ya que no existe una forma sin mediación -sin lenguaje y sin retórica- para acceder a ella. Así, Lihn se enfrenta al realismo testimonial como el estilo hegemónico para retratar la violencia. Algo similar sucede en el poema "De lo mismo" (Pena de extrañamiento 49-51), en donde, después de distinguir la imaginación de lo real, se presenta la tortura teatralmente para enfatizar el dramatismo y mostrar la indistinción entre actor y personaje. Si la manera de imaginar la tortura es a través de su escenificación, la forma para sobreponerse a esa estetización es afirmar la indistinción entre actor y personaje (denegación de la ficción). En esta paradoja referencial se mueve la teatralidad política de la poesía de Lihn.

Por otra parte, en A partir de Manhattan se encuentra una reflexión crítica sobre la televisión en donde la degradación del cuerpo es símbolo de la degradación subjetiva. También hay un espectáculo, pero su visibilidad es completa, por esto, es un símbolo de lo colectivo.

\section{T.V.}

Como los primitivos junto al fuego el rebaño se arremansa atomizado en la noche de las cincuenta estrellas, junto a la televisión en colores. De esa llama sólo se salvan los cuerpos

En cada hogar una familia a medio elaborar clava sus ojos de vidrio en el pequeño horno crematorio donde se abrasan los sueños La antiséptica caja de Pandora de la que brotan ofrecidos a la extinción del deseo meros objetos de consumo en lugar de signos, marcas de fábrica Hombres y mujeres reducidos por el showman a su primera infancia ancianas investidas de indignidad infantil juegan en la pantalla que destaca sus expresiones inestables como las de las cosas en el momento de arder.

(A partir de Manhattan 39)

Este poema proyecta sobre la imagen del televisor las figuras de la fogata y el horno crematorio - las que se relacionan por la luz, el fuego y la muerte- y en torno a ellas se elabora la posición del espectador. Primero, los espectadores son primitivos que miran el fuego - escena "originaria" de la sociedad-pero que en vez de hacerlo juntos, es decir, compartir la cercanía y la presencia, están separados y degradados socialmente: por eso están "atomizados" y con "sus familias a medio elaborar". En consecuencia, si la televisión toma el lugar 
de la fogata como experiencia visual, su función divide la comunidad y aliena. Esto se refuerza al proponer que los espectadores proyectan en la pantalla sus deseos y sueños, pero ella solo les devuelve elementos de la producción, circulación y consumo de mercancías en el capitalismo: "marcas" y "objetos de consumo". Como sostiene Guy Debord, la imagen ha devenido la forma extrema de la mercancía en el capitalismo contemporáneo, se ha vuelto un espectáculo (12) y frente a esto los sujetos se mantienen alineados y pasivos (23). "T. V" parece seguir la tesis general de Debord -y la idea anterior de la industria cultural como homogénea y manipulación de la Escuela de Frankfurt- y el final del poema consigue un giro teatral. La descripción del show en la pantalla también rebaja a los sujetos, ya sea al identificar vejez e infancia ("ancianas investidas de indignidad infantil") o al detenerse en la descripción de su gestualidad ("destaca sus expresiones inestables / como las de las cosas en el momento de arder"). La anciana no está en la televisión sino en un horno crematorio, en donde se dispone a ser quemada. De esta forma, la anciana (que toma el lugar de la actriz entregada a la mirada pública) es similar a los espectadores que la miran, pues a ambos les espera el fuego. En este poema, la confusión entre actor y espectador es dramática y fantástica: ambos se queman en la pantalla, ambos son consumidos y anulados.

Tortura y televisión son elementos opuestos en relación a su visibilidad, no obstante, ambos en la poesía de Lihn toman forma a partir de elementos teatrales. En "La realidad es el único libro que nos hace sufrir..." la tortura se escenifica teatralmente y después se propone una confusión entre personaje y actor. Frente a eso, la escena televisiva de "T. V." representa ese medio de comunicación como alienante, lo que se muestra en el cuerpo sufriente que será quemado. Así, el televisor se significa como un horno crematorio. Si bien tortura y televisión son opuestos en su visibilidad, ambos utilizan los recursos del otro para tomar forma, quizá debido a que ambos trabajan para un objetivo común durante la dictadura: la disciplina política de la población y la aceptación del liberalismo de mercado. Estos poemas de Lihn siguen la idea general de Debord de que en la sociedad de consumo la realidad social misma se funde con el espectáculo de los medios de comunicación de masas. Ya no se los puede oponer sencillamente. Sostiene Debord: "Cada noción así fijada no tiene otro fondo que su paso a lo opuesto: la realidad surge en el espectáculo, y el espectáculo es real. Esta alienación recíproca es la esencia y el sostén de la sociedad existente" (14).

La teatralidad y el espectáculo son los procedimientos principales con que la poesía de Enrique Lihn de los años 70 y 80 articula el espacio colectivo. 
En ellos muestra las conjunciones y disyunciones entre actor y personaje, espectador y mirada.

El paseo Ahumada presenta al sujeto popular empobrecido que deviene un actor privilegiado al ocupar el papel del mendigo en tan importante calle céntrica. Esta presentación del espacio urbano como teatro le permite al sujeto del poema distanciarse emocionalmente del mendigo. Con este distanciamiento, Lihn evita los procedimientos tradicionales de la poesía política: la empatía con el que sufre y su contraparte: la aspiración de redimirlo a través de la literatura.

El travesti de "El vaciadero" está determinado por la pobreza circundante, tal como le sucede al Pingüino, y ambos producen tanta atracción como repulsión, aunque más el primero. En otro lugar propuse entender al travesti como alegoría del capitalismo periférico ya que sostiene que el flujo detenido de esa calle es similar a la circulación de mercancías "en la traumática imposición del capitalismo en Chile en los años 70- donde los flujos de información y mercancías extranjeras deslumbran tanto como exhiben una falta de ajuste; donde el reciente sistema económico se muestra más artificial y ostenta más fuertemente las desigualdades" (Ayala 147). Esto es plausible al leer "El vaciadero" junto al El paseo Ahumada: si los mendigos de este son un símbolo de la pobreza del capitalismo en crisis, los travestis son su alegoría, ya que esos cuerpos abyectos son una inversión del fetichismo de la mercancía. Alegoría que probablemente sea más plausible -y devenga un símbolo patente- si se piensa, con Georges Bataille, la economía no desde la producción sino desde el gasto (110-134). Así, Bataille propone entender la sociedad no desde la producción, el intercambio y el consumo (y sus sistemas significantes que deben homogenizar para hacer circular) sino desde el gasto, los "desechos" y excesos que no pueden ser asimilados por la lógica social. Lo expulsado, social y corporalmente, como el excremento y los condenados, es inútil e inaprehensible (143).

El travesti de "La Efímera Vulgata" tiene cualidades distintas a las de "El vaciadero". De partida, no se ubica en Chile sino en Sidney (Australia), Nueva York (EE.UU.) y sobre todo, Sitges (España), por lo tanto, se trata de un travesti internacional. Por esto, no se relaciona directamente con la situación chilena, ya sea su capitalismo empobrecido o su dictadura. Estos travestis internacionales son individuos cuya mirada sobre sí mismos es fundamental, de tal forma que en "La Efímera Vulgata" se enfrenta esa mirada a la de los espectadores y esto causa la incompatibilidad entre actor y el personaje. El travesti que goza de su exhibición pública se encuentra de 
seguro en un lugar más "abierto" políticamente que en el Chile de los 80. En "Apología y condenación de las Ramblas" - de A partir de Manhattan- un poema sobre exhibición de travestis en Barcelona se los relaciona con el fin del régimen franquista. Los travestis en España representan el sujeto libertario por antonomasia. De hecho, el travesti se opone a la figura del sujeto lírico que construyen La pieza oscura y Poesía de paso: si en estos la formación del sujeto -es decir, la incorporación de la ley y el deseo-es traumática, por otra parte, los travestis son seres que no calzan en la ley, cuyo deseo escapa a la ley. Eso los hace únicos.

Los poemas finales sobre el espectáculo y tortura son muchos más directos en su carga política, pero al estar mediados por el espectáculo televisivo, el recurso ya no es el cruce de miradas imposible sino la confusión entre espectador y actor lo que produce el efecto principal. Como en el barroco -que confunde realidad y apariencia, fenómeno y representación- o ciertos discursos "postmodernos" que celebran o denuncian esta mediatización de la sociedad, la poesía de Lihn utiliza la teatralidad para dar forma a lo real, por esto es que elementos contradictorios, como la tortura y la televisión, se acercan en su despliegue poético.

\section{BIBLIOGRAFÍA}

Ayala, Matías. Lugar incómodo. Poesía y sociedad en Parra, Lihn y Martínez. Santiago: Ediciones Universidad Alberto Hurtado, 2010.

Bataille, Georges. La conjuración sagrada. Ensayos 1929-1939. Buenos Aires: Adriana Hidalgo Editora, 2003.

Borges, Jorge Luis. "Tlön, Uqbar, Orbis Tertius". Obras Completas, vol. I. Buenos Aires: Emecé, 1995. 431-43

Butler, Judith. Gender Trouble. London, New York: Routledge, 1990.

Cánovas, Rodrigo. Lihn, Zurita, Ictus, Radrigán: Literatura chilena y experiencia autoritaria. Santiago: FLACSO, 1986.

Correa-Díaz, Luis. "El cupido callejero de Enrique Lihn: poesía y ventriloquismo". Contra el canto de la goma de borrar: asedios a Enrique Lihn. Francisca Noguerol (ed.). Sevilla: Universidad de Sevilla, 2005. 135-145.

Debord, Guy. The Society of Spectacle. New York: Zone Books, 1995.

Egginton, William. How the World Became a Stage. Albany: State University of New York, 2003.

Favi, Gloria. "Enrique Lihn, cronista de ciudad". Revista Chilena de Literatura 43 (1993): 131-136. 
Foxley, Carmen. Enrique Lihn: Escritura excéntrica y modernidad. Santiago: Editorial Universitaria. 1995.

Galindo V., Óscar. "Escritura y viaje en la poesía de Enrique Lihn". Revista Chilena de Literatura 46 (1995): 101-110.

Kayser, Wolfgang. Lo grotesco. Su configuración en pintura y literatura. Buenos Aires: Editorial Nova, 1964.

Lacan, Jacques. "El estadio del espejo como formador de función del yo [je] tal como se nos revela en la experiencia psicoanalítica". Escritos 1. Buenos Aires: Siglo XXI editores, 2007. 99-105

Lastra, Pedro. "Notas sobre la poesía hispanoamericana actual". Revista Chilena de Literatura 25 (abril 1985): 131-138.

Lihn, Enrique. A partir de Manhattan. Valparaíso: Ediciones Ganymedes, 1979. “ “As a woman’ de Enrique Lihn”. Hora de poesía. 16-17 (1982): 113-118. El circo en llamas. Santiago de Chile: Lom Ediciones, 1997. El Paseo Ahumada. Santiago: Ediciones Minga, 1983. Enrique Lihn. Entrevistas. Daniel Fuenzalida (ed.). Santiago: J. C. Sáez, Editor, 2005. La pieza oscura. Santiago: Editorial Universitaria, 1963. La aparición de la virgen. Santiago: Cuadernos de libre(e)elección, 1987. Pena de extrañamiento. Santiago: Editorial Sinfronteras, 1986. Poesía de paso. La Habana: Casa de las Américas, 1966. Textos sobre arte. Santiago: Ediciones UDP, 2009.

Menninghaus, Winfried. Disgust. The Theory and History of a Strong Sensation. Albany: State University of New York Press, 2003.

Mulvey, Laura. "Placer visual y cine narrativo" (1975). Brian Wallis (ed.). Arte después de la modernidad. Nuevos planteamientos en torno a la representación. Madrid: Akal, 2001. 365-378.

Ostria, Mauricio. "Enrique Lihn o la desdicha sin respuesta". Revista de Crítica Literaria Latinoamericana 35 (1992): 49-60.

Rancière, Jacques. Le Partage du sensible. Esthétique et politique. París: La fabrique-éditions, 2000.

Valdés, Adriana. "Enrique Lihn: Santiago, París, Manhattan". Revista Chilena de Literatura 72 (2008): 89-113.

Weber, Samuel. Theatricality as Medium. New York: Fordham University Press, 2004.

Thomson, Philip. The Grotesque. London: Methuen (Criticial Idiom Series), 1972.

Travis, Christopher. Resisting Alienation: The Literary Work of Enrique Lihn. Bucknell University Press, 2007. 